\title{
Monetary Integration, Money-Demand Stability, and the Role of Monetary Overhang in Forecasting Inflation in CEE Countries
}

\author{
Claudiu Tiberiu ALBULESCU* \\ Management Department, Politehnica University of Timisoara, 2, P-ta. Victoriei, Timisoara, Romania. \\ Dominique Pepin \\ CRIEF, University of Poitiers, 2, Rue Jean Carbonnier, Bât. A1 (BP 623), 86022, Poitiers, France.
}

\begin{abstract}
This paper tests the stability of the money-demand function in selected Central and Eastern European countries and investigates the extent to which money helps predict inflation. We first show that long-run money demand is better described with an open-economy model, which considers a currency-substitution effect, rather than the closed-economy model used in several previous studies. From the estimated models, we derive two measures of monetary overhang. Then we compare the ability of open-economy model and closed-economy model based measures of monetary overhang to predict inflation in the CEE countries (i.e., the Czech Republic, Hungary, and Poland). Whereas we cannot detect a significant difference in forecast accuracy between the two competing models, we show that the open-economy model based forecast model that reveals a stable long-run money demand encompasses the closed-economy model based version.
\end{abstract}

\footnotetext{
* Corresponding Author : Claudiu Tiberiu ALBULESCU; Professor, Management Department, Politehnica University of Timisoara, 2, P-ta. Victoriei, 300006, Timisoara, Romania. Phone: +40 743089 759. Email: claudiual@yahoo.com.

Co-Author: Dominique Pepin; Associate Professor, CRIEF, University of Poitiers, 2, Rue Jean Carbonnier, Bât. A1 (BP 623), 86022, Poitiers, France.
}

Acknowledgement: This work was supported by a grant of the Romanian National Authority for Scientific Research and Innovation, CNCS - UEFISCDI, project number PN-III-P1-1.1-TE-2016-0142. 
JEL Classifications: E41, E47, E52, F41

Keywords: Monetary integration, Money demand stability, Monetary overhang, Inflation forecasts, Currency substitution, CEE countries

\section{Introduction}

The money-demand function, one of the most investigated macroeconomic relationships, is meant to help monetary authorities understand what motivates economic agents to hold money. The monetary authority can use this relationship to decide which monetary policies are recommended under specific economic conditions. The stability of the money-demand function shows that the money supply has a potential impact on both economic activity and inflation. Thus, a stable money demand shows how effective the use of monetary aggregates is in the conduct of monetary policy and to what extent money helps forecast inflation. This issue is very important for the Central and Eastern European (CEE) countries that are candidates to the Euro Area. The stability of money demand provides evidence about the countries' levels of monetary integration with the Euro Area countries and effectiveness of European Central Bank's (ECB) monetary strategy to ensure price stability. ${ }^{1}$

Money-demand stability is derived from the quantity theory of money, where money supply is exogenous, and money supply changes pass-through production and inflation (Bahmani 2008). Whereas modern monetary theory and the new Keynesian models have generally omitted moneydemand shocks in their empirical analysis of monetary policy (Biscarri et al. 2010), noteworthy recent studies (Teles et al. 2015, Benati et al. 2016) have proven that there is interest in investigating money-demand stability and the monetary overhang's role in predicting inflation (Horvath et al. 2011).

A glance through the literature reveals that the investigation of moneydemand stability has multiple implications in the conduct of monetary policy. It provides information about the choice of monetary policy instruments, the effects generated by money supply shocks on aggregate income, and the nexus between money and inflation.

Economists have long investigated the causes of high-inflation episodes, and one of the possible explanations is provided by the demand for

'ECB's long-term monetary analysis addresses the link between money and prices, where special attention is paid to the development of monetary aggregates and their implications for future inflation. 
money (Eckstein and Leiderman 1992). A stable money-demand function is associated with a long-run positive correlation between the money in circulation and the level of inflation, showing that money can predict inflation. A key issue here is the identification of monetary overhang or excess liquidity, because movements in money supply do not always match movements in money demand (El-Shagi and Giesen 2013). However, there is an increased interest in estimating the welfare cost of inflation (Attanasio et al. 2002). The calculation of the welfare cost assumes that the private sector expects the current inflation rate with positive effects on income and on inflation-targeting strategy (Miller et al. 2017).

Our paper adds to extant studies that investigate the stability of money demand and the role of monetary overhang in predicting inflation in CEE countries, in the context of their monetary integration with the Euro Area. The evaluation of money-demand stability remains a subject of interest for these countries, because their monetary policy tends to be oriented toward discretion rather than rules (Cziráky and Gillman 2006). After a successful disinflation process by these countries, their Euro Area accession became a subject of interest in the context of a new European Union (EU) framework and developing strategy. From the perspective of Euro Area enlargement, a stable money-demand function creates good preconditions for Euro adoption (Fidrmuc 2009). ${ }^{2}$ In addition, these countries adopted inflationtargeting regimes. Therefore, investigating the stability of money demand shows the effects of unexpected monetary shocks on the performance of inflation-targeting strategies. Furthermore, if the stability of money demand is documented, an important issue for these transition economies will be to see how much money helps predict inflation.

Despite the intensive empirical efforts to study the stability of money demand in CEE countries, there is no consensus regarding the existence or the absence of stability. This casts doubt on the role of money in forecasting inflation. The mixed empirical findings could be explained by a different specification of money-demand function used in previous studies. Cagan's (1956) constant semi-interest elasticity model served as a starting point for

\footnotetext{
${ }^{2}$ The white paper on the future of Europe released by the European Commission in March 2017, after the Brexit decision, presented several scenarios for the EU27 until 2025. Given the new commitment to a stronger EU and the election results of EU countries having strong Euroscepticism (i.e., France and the Netherlands), the last scenario, "Doing much more together," seems plausible. Thus, new member states are encouraged to join the Euro Area, but stronger fiscal coordination is necessary. In this context, understanding the determinants of money demand for the CEE countries is important for the conduct of the ECB monetary policy.
} 
many empirical works on money demand, focusing on the interest-rate role and investigating the stability of money-demand functions. Several early studies (Budina et al. 1995, Narayn 2010) employed this closed-economy formulation to compute the stability of money demand in CEE countries. Other works (Dreger et al. 2007, Fidrmuc 2009) resorted to a general formulation of the money-demand function, as did Leventakis (1993), who also considered open-economy factors.

Departing from extant empirical literature, we test the stability of money demand by comparing two competing models: the classic Cagan's (1956) closed-economy model (CEM) and Albulescu et al.'s (2018) open-economy model (OEM). This comparison allows us to explain the mixed findings reported in the existing literature about the stability of money demand. Additionally, the OEM model we use is a microfounded model, which differs from Leventakis's (1993) specification. It does not assume ex ante the existence of a direct currency substitution between domestic currencies and the euro. This model is compatible with both currency substitution and currency complementarity effects and is well adapted for CEE countries. It assumes that the euro offers liquidity services to the domestic representative agent, whereas the reverse is supposed not be true (for details, please refer to Albulescu et al. 2018). We resort to the Hansen's parameter instability test (Hansen 1992) to assess the cointegrating relationship and the stability of money demand. Furthermore, we estimate the long-run money-demand parameters with the fully modified ordinary least squares (FMOLS) method of Phillips and Hansen (1990).

Another contribution of our paper is the identification of the monetary overhang, derived from the OEM and CEM long-run equations. ${ }^{3}$ The purpose is to see to what extent the monetary overhang represents a good predictor of inflation in the Czech Republic, Hungary, and Poland from 1999 to 2016 (monthly data). Thus, we start from Stock and Watson's (1999) inflation-forecasting equation (i.e., out-of-sample and combined forecasting approaches). We further apply tests of equal forecast accuracy and encompassing tests (following Harvey et al. 1997, 1998). For robustness, we reduce our sample to the period 2004 2016 to see if the monetary

${ }^{3}$ The monetary overhang is associated with the residuals of the cointegration relationships. A positive monetary overhang is a sign of inflationary pressure. If, for example, the money demand proves to be unstable, this will bias the inflation forecasting results (Carstensen et al. 2009). 
overhang represents a reliable predictor of inflation in CEE countries after EU accession.

Our focus is on the advanced CEE countries for two reasons. First, we are constrained by data availability. As Cziráky and Gillman (2006) noticed, evaluating the stability of money demand in CEE countries is problematic because of the lack of confidence in data quality. To overcome this issue, we resort to international statistics for harmonization, without considering national databases, as most of the previous studies did. Second, the selected countries have in place floating exchange-rate regimes, and their degree of integration with the Euro Area is higher than other candidate countries (i.e., Bulgaria, Croatia or Romania). ${ }^{4}$

We discover that, in the long run, the open-economy specification of the money-demand model gives more consistent results than the closed-economy version. Furthermore, we show that the OEM-based monetary overhang is the best predictor of inflation for Hungary and Poland, especially for a long horizon. These findings are confirmed by our robustness analysis.

The rest of the paper is constructed as follows. Section 2 presents the money-stabilization literature. Section 3 is dedicated to the analysis of the demand for money stability, comparing the performance of a closed- and an open-economy money-demand model. Section 4 addresses the monetary overhang and the inflation forecast in the selected CEE countries. Section 5 presents the robustness analysis. The last section concludes and presents the policy implications of our findings.

\section{Money-Demand Stabilization: Review of the Literature}

Quantity theorists have long maintained that the demand for money is highly stable, underlining its importance for transmission of monetary impulses into prices. However, during the 1980s, several elements (e.g., financial innovations and the deregulation process) put into question the concept of money-demand stability (Lucas and Nicolini 2015). Starting with Friedman and Kuttner (1992), who reported a break in the cointegration

\footnotetext{
${ }^{4}$ Whereas Croatia and Bulgaria recently affirmed their intention to join the Euro Area, it is expected that Euro-Area enlargement will start with the Czech Republic, Hungary, and Poland. The European authorities are cautious regarding the Euro-Area extension and, aside from the Maastricht criteria, they discuss the level of real convergence and institutional performance. In this context, the 'advanced' CEE countries remain favored for Euro-Area enlargement.
} 
relationship around 1980 for the United States (US), a new instability literature emerged, characterized by the consideration within the moneydemand function of substitutes for money. Furthermore, the focus on monetary policy rules (Taylor 1999) introduced the perception of policy irrelevance of money-demand theory (Cziráky and Gillman 2006). Alvarez et al. (2001) underlined the ongoing role of money for the equivalence between interest-rate and money supply rules. Nevertheless, the role of money in forecasting inflation is still of great interest (Horváth et al. 2011).

The empirical literature on money-demand stabilization usually resorts to simultaneous equations, cointegration analyses, and consecrated stability tests, i.e., recursive residuals approaches (CUSUM, CUSUMSQ) or Chow tests. Most studies addressed developed economies, whereas few empirical works were oriented toward emerging economies and CEE countries. ${ }^{5}$

Early studies in this area focus on the U.S. economy and showed mixed evidence. Laumas and Mehra (1977) examined the stability of the U.S. money demand, using annual data for the period from 1900 to 1974 . Their varying parameter technique, which regressed money on income and interest rates, showed that money demand was not stable. Opposite findings were advanced by Lin and Oh (1984), who employed switch-regression techniques and documented money-demand stability. These results were confirmed by recent works on the postwar stability of money demand in the United States. Along these lines, Arize et al. (2012) examined the long-run stability of money demand using the Johansen cointegration technique. Furthermore, Miller et al. (2017) resorted to nonlinear cointegration techniques and documented the stability of money demand in the United States.

Studies on money-demand stability in the EU are generally oriented on Euro Area monetary stabilization as a whole, whereas few have approached the case of Euro Area individual countries (for a recent review of the literature, refer to Liu and Kool 2018). Thus, Clausen and Kim (2000) underlined the stability of Euro Area money demand and stated that the ECB should follow the monetary targeting strategy. Golinelli and Pastorello (2002) showed that the area-wide money demand was more stable than the single-country one, whereas Brand and Cassola (2004) and Coenen and Vega

${ }^{5}$ Estimates of the demand for money stability are familiar for developed countries (Ewing and Payne 1999, Kumar and Webber 2013, Makin et al. 2017), and are of great interest for emerging economies. In the latter case, the stability of money demand and the monetary overhang are investigated inter -alia by Wu et al. (2003) for Taiwan, Rao and Kumar (2009) for a set of Asian countries, and Delatte et al. (2014) for China. Most of these works reported stable money-demand functions. 
(2001) reaffirmed the stability of money demand at the aggregate level. Belke and Czudaj (2010) investigated money demand at the aggregate level and compared cointegrated VAR and single-equation techniques. The authors posited that the recent financial crisis had no noticeable impact on the stability of money demand.

With a focus on the same aggregate level, De Santis et al. (2013) adopted a different approach and argued that a stable, broad money demand for the Euro Area could be obtained by modeling cross-border international portfolio allocations. Furthermore, applying Johansen's (1995) cointegration method and Nyblom's (1989) time-invariance parameter test, the authors reported a strong comovement between net cross-border portfolio flows and M3 velocity growth. Dreger and Wolters (2014) analyzed the stability of money demand in the Euro Area and the inflation-forecasting performances of a broad monetary aggregate. They stated that the evolution of M3 was in line with the money demand.

Adopting a different strategy, Setzer and Wolff (2013) focused on the stability of money demand for the selected Euro Area countries, using disaggregated data. Their cointegration relationship was generated from a microfounded money-demand model. Their results showed that the income and the interest-rate elasticity remained stable over time. Capasso and Napolitano (2012) added more evidence to the stability of money demand in the Euro Area countries. With a focus on Italy over the period 1977 to 2007, and by using bounds-testing cointegration, the authors showed that the introduction of the euro contributed to money-demand stability.

The interest for assessing the stability of money demand in the Euro Area increased after the recent global-crisis outburst, but it progressively vanished with the conduct of unconventional monetary policy by the ECB. Similarly, the uncertainty generated by the crisis regarding Euro Area enlargement diminished the interest for assessing the stability of money demand in CEEs. However, the stability of money demand in the Euro Area candidate countries remains a subject of great interest for researchers and policymakers.

The bulk of empirical literature on the monetary stabilization in CEE countries is divided into panel data and time-series analyses. Given the fact that, during the 1990s, the CEE transition economies registered noteworthy structural changes that made it difficult to access data for a long sample period, the first set of studies used panel data. Thus, Dreger et al. (2007) 
employed panel cointegration methods and quarterly data for the period 1995 to 2004 and reported the existence of a long-run relationship in the moneydemand equation. Similarly, Fidrmuc (2009) did not find any structural breaks in the series, concluding that the money demand was stable in CEE countries, even if it was largely influenced by the Euro Area interest rates and by the exchange-rate against the euro, which might represent signs of instability. Applying Hansen's (1992) parameter stability test for a panel of eight transitional economies for the period 1995 to 2005, Narayan (2010) found the existence of a long-run relationship but revealed more cases of unstable money-demand functions.

Simultaneously, beginning with Chawluk and Cross (1997), researchers became interested in the existence and the size of a monetary overhang to predict the inflation in the CEE countries. However, the first study that investigated the stability of money demand in individual post-communist economies was that of Buch (2001). Using a cointegration and errorcorrection framework and a CUSUM test for the coefficient stability, the author documented the stability of money demand in Hungary and Poland. Cziráky and Gillman (2006) estimated the money demand in Croatia using monthly data from 1994 to 2002. They found evidence for a stable moneydemand function, representing the basis for inflation rate forecasting in Croatia. Subsequent studies enlarged the group of the analyzed countries. Using a bounds-testing approach to error-correction modeling and cointegration, Bahmani and Kutan (2010) showed that money demand for CEE countries was quite stable. Furthermore, Bahmani-Oskooee et al. (2013) introduced uncertainty and monetary volatility in the money-demand equation for six CEE and four other emerging economies. Pesaran et al.'s (2001) bounds-testing approach showed that the money demand was correctly specified and stable.

To the best of our knowledge, no previous study has investigated the stability of money demand, comparing concurrent money-demand functions relying on closed- and open-economy models. Moreover, no previous moneydemand function employed for testing the monetary stabilization in the CEE countries has been specifically designed to fit the particularities of CEE economies. To fill in this gap, we compare the stability of money demand, resorting to a closed- and an open-economy money-demand model. We also compare the performance of the monetary overhang obtained, based on these 
competing models, to forecast inflation in selected CEE countries.

\section{Money Demand in the Long Run}

In this section, we describe two competing long-run money-demand functions and present the estimated models for Hungary, the Czech Republic, and Poland. The monthly data period is from January 1999 through November 2016. Details are provided in Appendix 1.

The first model is a standard closed-economy model (CEM) that relates the real money demand to a scale variable (i.e., the real industrial production) and to a domestic interest rate. We employ the semilog form used by Cagan (1956) and recommended by Ireland (2009), which explains the log of the real money demand by the log of the scale variable and the level of the interest rate:

$$
\ln \left(m_{t}\right)=\alpha_{0}+\alpha_{1} \ln \left(y_{t}\right)+\alpha_{2} r_{t}+\varepsilon_{t}
$$

with $m_{t}=M_{t} / P_{t}$, where $M, P, y$ and $r$ are defined as money (M3 aggregate), prices, output (real industrial production), and domestic interest rate. ${ }^{6} \alpha_{0}$ is a positive constant, $\alpha_{1}$ is the output elasticity, and $\alpha_{2}$ is the absolute value of the interest semi-elasticity of money demand.

The second model is a modified version of the open-economy model (OEM) of Albulescu et al. (2018). ${ }^{7}$ In this model, the agents of CEE countries hold domestic and foreign assets (i.e., bonds and currencies). The foreign currency is the euro, which is supposed to offer liquidity services to the agents of the CEE countries. Currency substitution is demonstrated to relate the money demand to the interest rate spread between the CEE countries and the Euro Area, plus the scale variable to the domestic interest rate. Thus, we include the interest-rate spread in the open-economy formulation of money

\footnotetext{
${ }^{6}$ The M3 aggregate is represented by the broad money index $(2010=100)$ and comes from the OECD database. Bruggeman et al. $(2003)$, Carstensen et al. (2009), and Dreger and Wolters, (2014) used the M3 aggregate to check the stability of money demand in the Euro Area. The level of prices (consumer price index $-2010=100)$ and the real industrial production index $(2010=100)$ comes from IMF's -International Financial Statistics database. The interest rate (one-month money- market rate) comes from the Eurostat database. Except for the interest rate, all other series are seasonally adjusted, as in Fidrmuc (2009).

${ }^{7}$ To make relevant the comparisons between CEM and OEM, we consider a semilog form of OEM, whereas Albulescu et al. (2018) used a $\log -\log$ specification. The semilog form is also implied by the fact that, during the analyzed time span, we recorded periods with negative interest rates.
} 
demand:

$$
\ln \left(m_{t}\right)=\alpha_{0}+\alpha_{1} \ln \left(y_{t}\right)+\alpha_{2} r_{t}+\alpha_{3}\left(r_{t}-r_{t}^{*}\right)+\varepsilon_{t}
$$

where $r^{*}$ is the Euro Area interest rate. The parameter, $\alpha_{3}$, can have any sign, depending on the elasticity of substitution between consumption and liquidity, which is a function of domestic and foreign money, and the elasticity of substitution between domestic and foreign money. $\alpha_{3}$ is positive if substitutability between consumption and liquidity is higher than substitutability between foreign and domestic money, and negative otherwise (Albulescu et al. 2018). If liquidity and consumption are complementary in the CEE countries (Albulescu et al. 2018), the positivity of $\alpha_{3}$ is a sign of complementarity between the CEE currencies and the euro.

In the long run, the model is supposed to perfectly fit the data, so that the error term, $\varepsilon_{t}$, is zero. However, in the short run, money demand deviates from the long-run function, giving rise to a nonzero stationary error term, $\varepsilon_{t}$. The closed-economy version of the model is simply obtained with the restriction $\alpha_{3}=0$.

For each model and each country, we estimate the long-run money-demand parameters with the FMOLS method of Phillips and Hansen $(1990)^{8}$ and perform a cointegration test with Hansen's parameter instability test (Hansen 1992). ${ }^{9}$ The theoretical money-demand model adds restrictions that the output elasticity is one $\left(\alpha_{3}=1\right)$. Additionally, the interest-rate semi-elasticity is negative $\left(\alpha_{2}<0\right)$. We pay close attention to these hypotheses.

Table 1 presents the long-run estimated parameters. It appears that the OEM offers more consistent results than the CEM. Indeed, the estimated interest semi-elasticity is always negative and significant, whereas the same estimated parameter is positive in two out of three cases when the closedeconomy specification is considered. Moreover, all parameters of the OEM are significant, notably the interest spread between the CEE countries and the Euro Area. The estimated parameter, $\alpha_{3}$, is positive for the three CEE countries, demonstrating that preference parameters are quite homogeneous

${ }^{8}$ The DOLS estimator of Saikkonen (1991) and Stock and Watson (1993) is another method for estimating cointegration regressions. Both methods have similar asymptotic properties, but FMOLS is more frequently used to estimate money- demand equations. For small samples, such as ours, FMOLS non-parametrically presents an advantage that corrects for endogeneity and serial correlation to the OLS estimator.

${ }^{9}$ Narayan (2010) used a similar approach in his panel- data analysis for the stability of money demand in eight CEE countries. 
among CEE countries.

It appears from Table 1 that the estimated output elasticities are not too far from the unity. For the OEM, the sign of $\alpha_{2}$ is negative, meaning that a higher opportunity cost of holding the domestic and foreign money determines a decrease in money demand. Additionally, the sign of $\alpha_{3}$ is positive, and the coefficient $\alpha_{3}>\left|\alpha_{2}\right|$, showing that a decrease in the opportunity cost of foreign money leads to an increase in domestic money demand. This result underlines the fact that CEE currencies and the euro are complements rather than substitutes. This is in line with the findings advanced by Albulescu et al. (2018).

Table 1. Estimation results

\begin{tabular}{|c|c|c|c|c|c|c|}
\hline \multirow{2}{*}{$\begin{array}{c}\text { Coeffi- } \\
\text { cient }\end{array}$} & \multicolumn{2}{|c|}{ Hungary } & \multicolumn{2}{c|}{ Czech Republic } & \multicolumn{2}{c|}{ Poland } \\
\cline { 2 - 7 } & OEM & CEM & OEM & CEM & OEM & CEM \\
\hline \multirow{2}{*}{$\alpha_{0}$} & $-5.195 * * *$ & $-4.867 * * *$ & $-6.125^{* * *}$ & $-3.012^{* * *}$ & $-6.311^{* * *}$ & $-7.007 * * *$ \\
& $(-10.764)$ & $(-8.824)$ & $(-9.310)$ & $(-5.394)$ & $(-20.310)$ & $(-17.099)$ \\
\hline \multirow{2}{*}{$\alpha_{1}$} & $1.093 * * *$ & $1.030 * * *$ & $1.319 * * *$ & $1.129 * * *$ & $1.367 * * *$ & $1.510 * * *$ \\
& $(11.083)$ & $(9.126)$ & $(9.439)$ & $(5.484)$ & $(20.961)$ & $(17.479)$ \\
\hline \multirow{2}{*}{$\alpha_{2}$} & $-0.013 *$ & 0.002 & $-0.021 *$ & -0.018 & $-0.025 * * *$ & $0.012 * * *$ \\
& $(-1.735)$ & $(0.391)$ & $(-1.737)$ & $(-0.977)$ & $(-2.962)$ & $(2.649)$ \\
\hline \multirow{2}{*}{$\alpha_{3}$} & $0.027 * * *$ & & $0.096 * * *$ & & $0.041 * * *$ & \\
\hline
\end{tabular}

(Notes) (i) The $t$-statistics are in bracket below the estimated long run parameters

(ii) $* * *, * *$, means significance at $1 \%, 5 \%$ and $10 \%$ significance level.

Table 2 presents the results of the test of hypothesis, $\alpha_{1}=1$, for each country and each model. The hypothesis of a unitary output elasticity cannot be rejected for Hungary and Czech Republic, whereas the hypothesis is rejected for Poland. Nevertheless, the estimated parameter is rather close to the unity, particularly for the case of an OEM. 
Table 2. Tests of the hypothesis $\alpha_{1}=1$

\begin{tabular}{|c|c|c|c|c|c|c|}
\hline \multirow{2}{*}{} & \multicolumn{2}{|c|}{ Hungary } & \multicolumn{2}{c|}{ Czech Republic } & \multicolumn{2}{c|}{ Poland } \\
\cline { 2 - 7 } & OEM & CEM & OEM & CEM & OEM & CEM \\
\hline $\begin{array}{c}t \text {-statistic } \\
\text { (probability) }\end{array}$ & 0.951 & 0.270 & 2.284 & 0.627 & 5.633 & 5.909 \\
$(0.342)$ & $(0.787)$ & $(0.023)$ & $(0.530)$ & $(0.000)$ & $(0.000)$ \\
\hline
\end{tabular}

Table 3 presents the results of cointegration tests performed according to Hansen's parameter instability test (Hansen 1992). The hypothesis that $m, y$, and $r$ are cointegrated is not plausible, because the $p$-value of the cointegration test of the CEM never exceeds 0.01. However, the hypothesis that $m, y, r$, and $r-r^{*}$ are cointegrated is plausible, except for the Czech Republic, where the assumption of stationarity of the error term, $\varepsilon_{t}$, is questionable.

To summarize, the open-economy specification of the money-demand model gives more consistent results than the closed-economy version, consistent with a long-run relationship between the variables for Hungary and Poland. The hypothesis of cointegration is more doubtful in the case of the Czech Republic. ${ }^{10}$

Table 3. Results of the cointegration tests (Hansen's parameter instability tests)

\begin{tabular}{|c|c|c|c|c|c|c|}
\hline \multirow{2}{*}{} & \multicolumn{2}{|c|}{ Hungary } & \multicolumn{2}{c|}{ Czech Republic } & \multicolumn{2}{c|}{ Poland } \\
\cline { 2 - 7 } & OEM & CEM & OEM & CEM & OEM & CEM \\
\hline LC statistic & 1.035 & 0.698 & 1.198 & 1.372 & 0.637 & 0.882 \\
(probability) & $(0.019)$ & $(0.010)$ & $(<0.01)$ & $(<0.01)$ & $(0.123)$ & $(<0.01)$ \\
\hline
\end{tabular}

Next, we define the monetary overhang for each country and each model as the residual of the long-run money-demand equations:

$$
\hat{\varepsilon}_{t}=\ln m_{t}-\ln \widehat{m}_{t}
$$

\footnotetext{
${ }^{10}$ To check the robustness of these results, we perform a similar analysis for the period of 2004 2016 (the moment of the three CEE countries' EU accession up to the present). This set of results is presented in Appendix B and confirm the existence of a long-run relationship (see Tables B1, B2, and B3).
} 
Figures 1, 2, and 3 illustrate the differences between the two measures of monetary overhang.

Figure 1. Monetary overhang of Hungary

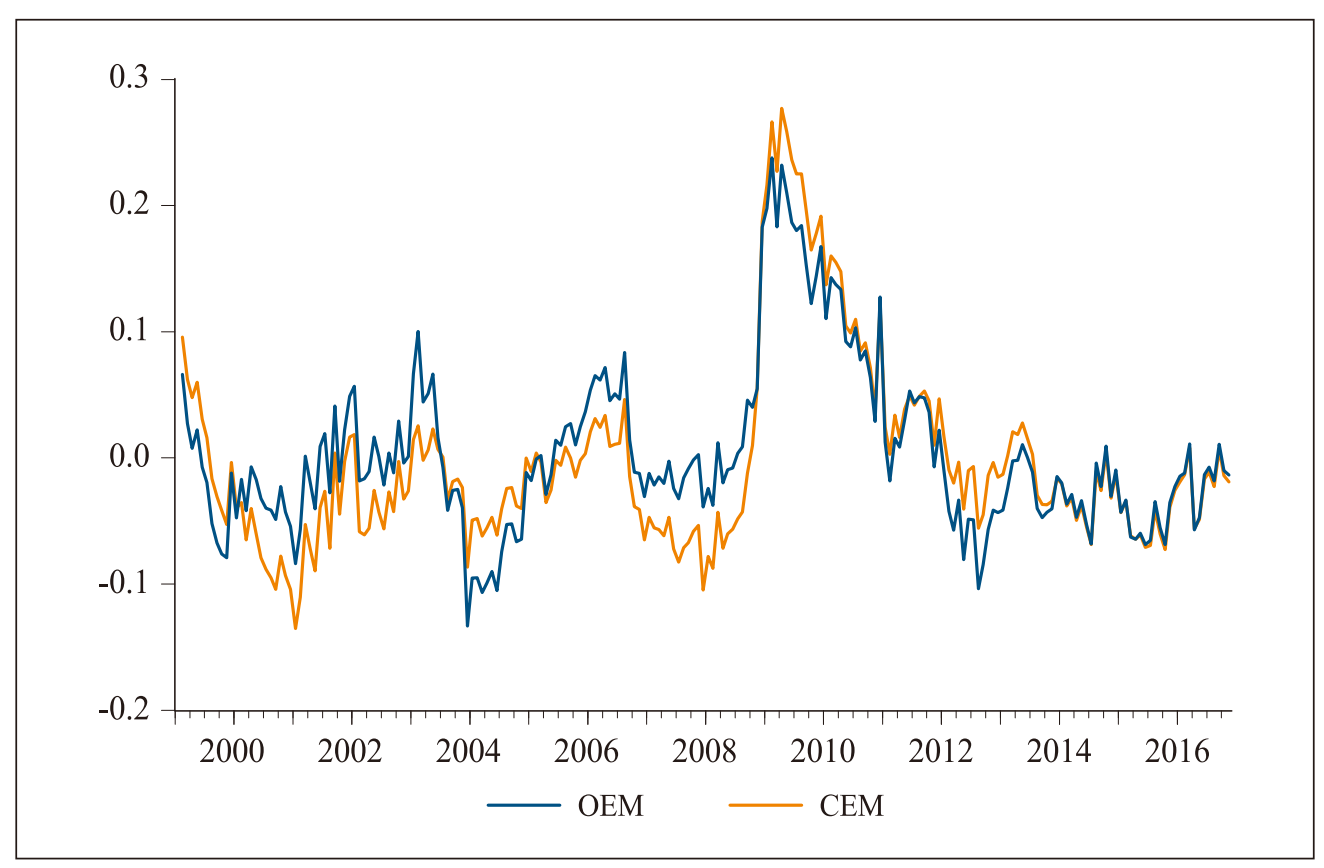


Figure 2. Monetary overhang of the Czech Republic

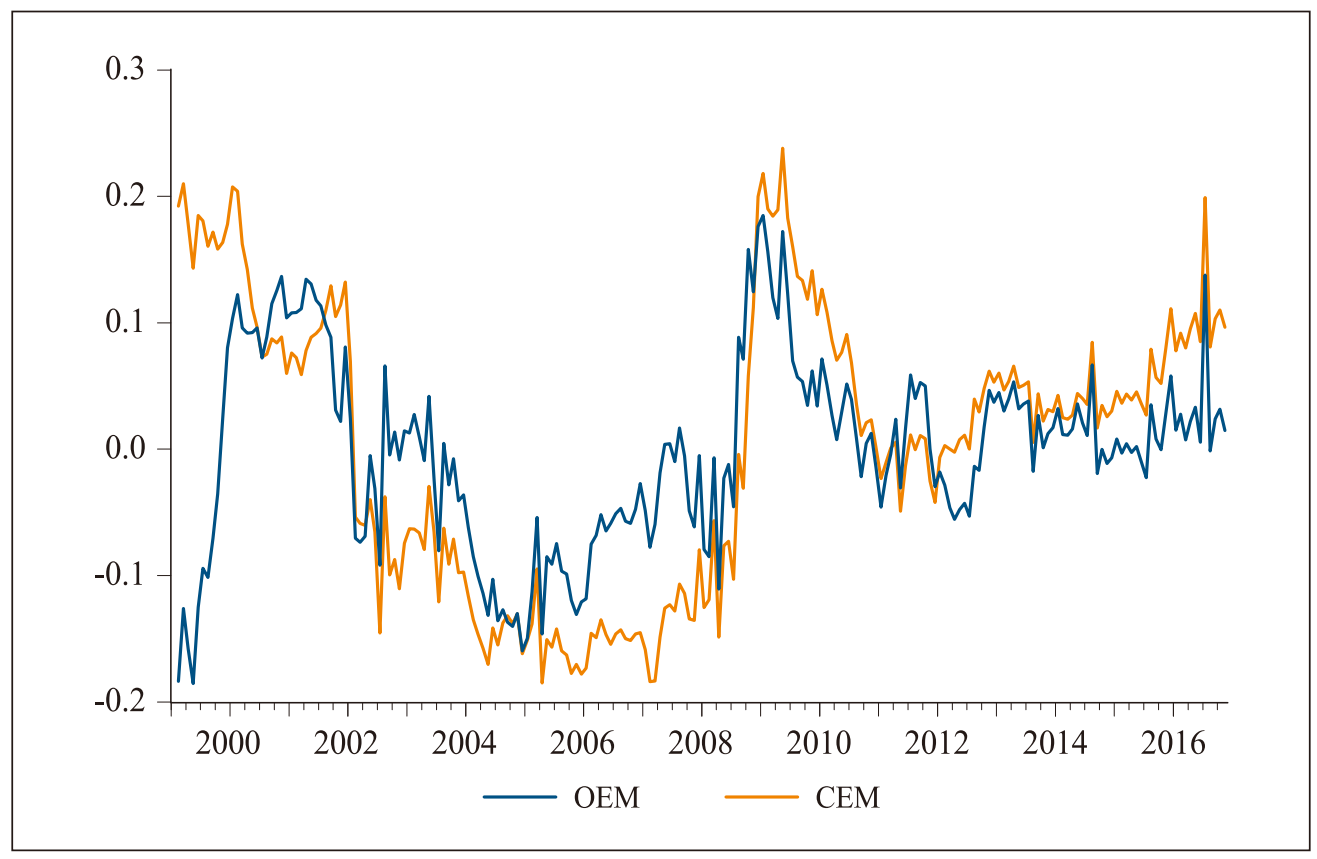

Figure 3. Monetary overhang of Poland

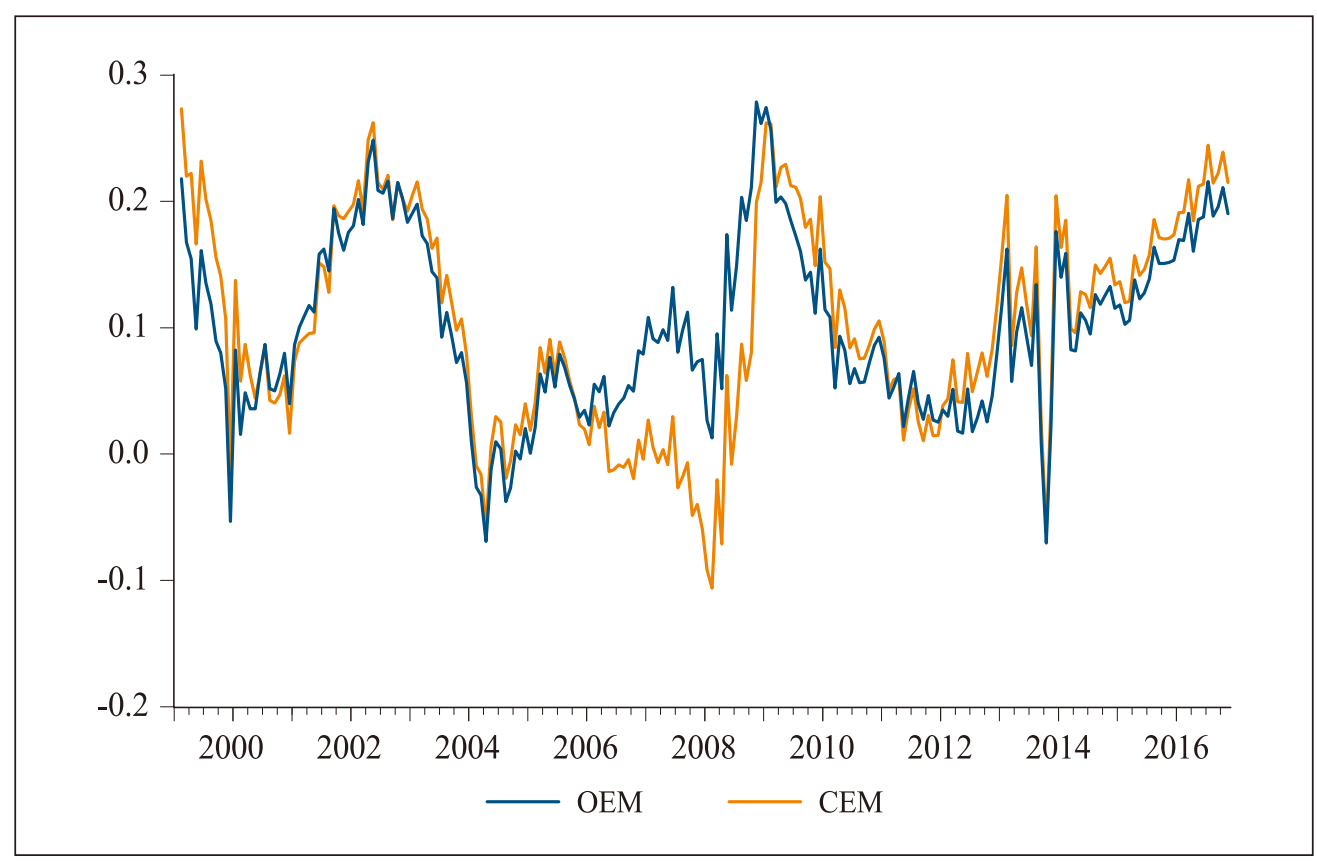


There are noticeable differences between these measures, especially for the Czech Republic and Poland. Moreover, we notice that the monetary overhang estimated from the OEM surpasses the monetary overhang estimated from the CEM for the three CEE countries during the pre-crisis period: 2006 2008. We also see that both measures of monetary overhang skyrocketed at the beginning of the 2008 financial crisis.

\section{Monetary Overhang and Inflation Forecast}

It is generally accepted that the existence of a stable long-run moneydemand function implies that the monetary overhang is a good leading indicator of inflation. Thus, we study and compare the inflation-forecasting properties of the two measures of monetary overhang. Therefore, we consider inflation-forecasting for different forecast horizons, $h$ : one month $(h=1)$, one quarter $(h=4)$, one year $(h=12)$, and two years $(h=24) .{ }^{11}$ We follow Stock and Watson (1999) to specify the inflation-forecasting equation:

$$
\pi_{t+h}^{h}-\pi_{t}=\beta+\beta_{\pi}(L) \Delta \pi_{t}+\beta_{\widehat{\varepsilon}}(L) \hat{\varepsilon}_{t}+\eta_{t+h}
$$

where $\pi_{t}=12 \times \ln \left(P_{t} / P_{t-1}\right)$ is the annualized monthly inflation rate in the price level, $P_{t}, \pi_{t+h}^{h}=(12 / h) \times \ln \left(P_{t+h} / P_{t}\right)$ is the annualized h-period inflation rate, $\hat{\varepsilon}_{t}$ is one of the two measures of monetary overhang, $\Delta$ is the difference operator, $\beta_{\pi}(L)$ and $\beta_{\hat{\varepsilon}}(L)$ are lag polynomials, and $\eta_{t+h}$ is an error term.

It is important to note that the CEM-based inflation-forecasting equation is not nested in the OEM-based version, whereas the CEM is nested in the OEM. We have shown that the OEM better describes the long-run money demand in CEE countries. Nevertheless, this result does not imply that the OEM-based monetary overhang has better forecasting properties for the future inflation than the CEM-based monetary overhang. To compare the forecasting performances of these two measures of monetary overhang, we implement tests of equal forecast accuracy and encompassing tests.

\footnotetext{
${ }^{11}$ It is well known since Friedman and Schwartz (1963) that the delays in monetary-policy transmission to output and then to prices are very long, situated between one and two years. Belongia and Ireland (2016) confirmed the existence of such delays and suggested they could be even longer today. A priori, we think that it is easier to predict inflation over a period of one or two years than on a horizon of one or three months. Carstensen et al. (2009) considered, a forecast horizon of up to two years.
} 
To estimate equation (04), we follow Carstensen et al. (2009) and fix the lag order of the polynomials $\beta_{\pi}(L)$ and $\beta_{\hat{\varepsilon}}(L)$ to 12 , because the data are monthly. ${ }^{12}$ In Table 4 , we test the overall significance of the regression for each country and each measure with the $F$-statistic. In Table 5 , we report for each country and each measure the $F$-statistic and the p-value of the hypothesis that the monetary overhang measure can be excluded from the equation. The parameters of the lag polynomial $\beta_{\hat{\varepsilon}}(L)$ are all zero.

First, the results of overall significance tests of the forecasting models show that inflation is predictable at any horizon between one month and two years. As expected, it is easier to forecast inflation at long-run horizons (one to two years) than in the short run (one to three months). The results also seem to indicate that the performances of the two models are very similar on short horizons. However, some differences appear for long horizons.

Table 4. Tests of the overall significance of the inflation forecasting model $(F$-statistic)

\begin{tabular}{|c|c|c|c|c|}
\hline \multicolumn{2}{|c|}{} & Hungary & Czech Republic & Poland \\
\hline \multirow{3}{*}{$h=1$} & MO based on OEM & $5.229(0.000)$ & $6.849(0.000)$ & $3.571(0.000)$ \\
\cline { 2 - 5 } & MO based on CEM & $5.260(0.000)$ & $6.750(0.000)$ & $3.416(0.000)$ \\
\hline \multirow{3}{*}{$h=3$} & MO based on OEM & $10.164(0.000)$ & $11.475(0.000)$ & $7.962(0.000)$ \\
\cline { 2 - 5 } & MO based on CEM & $10.011(0.000)$ & $11.477(0.000)$ & $7.614(0.000)$ \\
\hline \multirow{3}{*}{$h=12$} & MO based on OEM & $19.845(0.000)$ & $13.339(0.000)$ & $9.408(0.000)$ \\
\cline { 2 - 5 } & MO based on CEM & $17.566(0.000)$ & $13.642(0.000)$ & $8.779(0.000)$ \\
\hline \multirow{2}{*}{$h=24$} & MO based on OEM & $22.281(0.000)$ & $16.257(0.000)$ & $7.537(0.000)$ \\
\cline { 2 - 5 } & MO based on CEM & $18.463(0.000)$ & $17.511(0.000)$ & $6.779(0.000)$ \\
\hline
\end{tabular}

(Note) $P$-values of the hypothesis of nullity of the parameters of $\beta_{\pi}(L)$ and $\beta_{\hat{\varepsilon}}(L)$ are reported in brackets.

${ }^{12}$ Carstensen et al. (2009) set the lag order to four, because their data were quarterly. 
Table 5. Tests of exclusion of the monetary overhang (MO) measures in the forecasting regressions

\begin{tabular}{|c|l|c|c|c|}
\hline \multicolumn{2}{|c|}{} & Hungary & Czech Republic & Poland \\
\hline \multirow{2}{*}{$h=1$} & MO based on OEM & $1.195(0.285)$ & $0.723(0.738)$ & $0.611(0.842)$ \\
\cline { 2 - 5 } & MO based on CEM & $1.234(0.258)$ & $0.620(0.835)$ & $0.399(0.968)$ \\
\hline \multirow{3}{*}{$h=3$} & MO based on OEM & $1.818(0.043)$ & $0.261(0.995)$ & $1.085(0.374)$ \\
\cline { 2 - 5 } & MO based on CEM & $1.681(0.068)$ & $0.263(0.995)$ & $0.744(0.717)$ \\
\hline \multirow{2}{*}{$h=12$} & MO based on OEM & $3.183(0.000)$ & $0.898(0.556)$ & $1.590(0.092)$ \\
\cline { 2 - 5 } & MO based on CEM & $1.816(0.044)$ & $1.105(0.358)$ & $1.026(0.428)$ \\
\hline \multirow{2}{*}{$h=24$} & MO based on OEM & $4.027(0.000)$ & $1.409(0.160)$ & $2.077(0.018)$ \\
\cline { 2 - 5 } & MO based on CEM & $1.908(0.033)$ & $2.146(0.014)$ & $1.302(0.217)$ \\
\hline
\end{tabular}

(Note) $P$-values of the hypothesis of nullity of the parameters of $\beta_{\hat{\varepsilon}}(L)$ are reported in brackets.

Next, the results of the monetary overhang exclusion tests are globally consistent with the results of the cointegration tests. For the Czech Republic, monetary overhang measures are not good predictors of future inflation, whatever the forecasting horizon, except for the monetary overhang based on the CEM, which predicts inflation at a horizon of two years. This result is not surprising, because we show that the hypothesis of stationarity of monetary overhang is doubtful in the case of the Czech Republic. For Hungary and Poland, the monetary overhang, based on OEM, gives a better prediction of future inflation at all horizons than the monetary overhang based on CEM, in the sense that the probabilities are lower. Inflation seems to be unpredictable by the monetary overhang at a very short horizon (e.g., one month). At a horizon of one quarter, monetary overhang shows a significant ability to predict inflation in the case of Hungary. Furthermore, at a horizon of one and two years, we cannot exclude for Hungary and Poland the monetary overhang from the forecasting regression, especially when the OEM-based measure is used. The monetary overhang measure using CEM is a significant predictor of inflation in the case of Hungary, but not in the case of Poland.

To gain further insights into the forecasting ability of monetary overhang measures, we follow Stock and Watson (1999) and Carstensen et al. (2009) and perform forecasting comparisons using a recursive out-of-sample 
methodology for the last five years of the sample (from January 2012 to November 2016). For each model, the prediction error at horizon $h$, given a forecast, carried out at date $t$, is:

$$
e_{t, h}=\pi_{t+h}^{h}-f_{t, h}
$$

where $f_{t, h}$ is the forecast based on Equation (4). The root mean-squared prediction errors (RMSPE) at horizon $h$ are defined as

$$
\operatorname{RMSPE}(h)=\sqrt{\frac{\sum_{t=1}^{N}\left(e_{t, h}\right)^{2}}{N}}
$$

Table 6 displays the RMSPE for the two models, for each country, and for $h=1,3,12$, and 24. First, we notice for all countries that the RMSPE is a decreasing function of $h$ up to a horizon of $h=12$. Then, it decreases for Hungary and Poland when $\mathrm{h}$ increases from 12 to 24. Whatever the model, the best predictions of inflation are obtained with a horizon of a year for Czech Republic and Poland. For Hungary, the best predictions are obtained with a horizon of one or two years, depending on the model. Finally, when we consider the out-of-sample comparison of CEM- and OEM-based forecasting regressions, the RMSPE indicates that, for Hungary and Poland, the best predictor is based on OEM, respectively at horizons of two years and one year, whereas for Czech Republic it is based on the CEM at a horizon of one year. 
Table 6. Root mean-squared prediction errors (RMSPE)

\begin{tabular}{|c|l|c|c|c|}
\hline \multicolumn{2}{|c|}{} & Hungary & Czech Republic & Poland \\
\hline \multirow{3}{*}{$h=1$} & MO based on OEM & 0.0374 & 0.0302 & 0.0206 \\
\cline { 2 - 5 } & MO based on CEM & 0.0383 & 0.0301 & 0.0204 \\
\hline \multirow{3}{*}{$h=3$} & MO based on OEM & 0.0262 & 0.0178 & 0.0163 \\
\cline { 2 - 5 } & MO based on CEM & 0.0275 & 0.0182 & 0.0166 \\
\hline \multirow{3}{*}{$h=12$} & MO based on OEM & 0.0179 & 0.0146 & 0.0112 \\
\cline { 2 - 5 } & MO based on CEM & 0.0200 & 0.0131 & 0.0120 \\
\hline \multirow{3}{*}{$h=24$} & MO based on OEM & 0.0174 & 0.0169 & 0.0143 \\
\cline { 2 - 5 } & MO based on CEM & 0.0204 & 0.0139 & 0.0162 \\
\hline
\end{tabular}

These results are consistent with those of the cointegration tests (Table 3). If the hypothesis of cointegration is doubtful (i.e., the Czech Republic), the RMSPE indicates that the OEM-based money overhang does not improve the forecast of inflation vis-a-vis the CEM-based monetary overhang. However, comparison of point estimators (i.e., RMSPE) is only indicative, and we cannot conclude that the forecast accuracy of the two models is significantly different. Additionally, we cannot be sure that one measure does not contain information already contained in the other.

To test the hypothesis of equal forecast accuracy, we follow Harvey et al. (1997) and use the MDM statistic, which is an adjustment for a moderatesized sample of the DM statistic of Diebold and Mariano (1995).

We denote $d_{t}$ as the loss differential, $d_{t}=\left(e_{t}^{C E M}\right)^{2}-\left(e_{t}^{O E M}\right)^{2}$, where $e^{C E M}$ and $e^{O E M}$ are the two forecast errors associated with the two models. Diebold and Mariano (1995) proposed a test for the null hypothesis of equal forecast accuracy based on the sample mean-loss differential, $\bar{d}$. Their test statistic was $\mathrm{DM}=\bar{d} / \sigma_{\bar{d}}$, where $\sigma_{\bar{d}}$ was a consistent estimator of the standard deviation of $\bar{d}$ , robust to heteroscedasticity and auto-correlation of order $h-1$. The asymptotic distribution of DM is the standard normal distribution. Harvey et al. (1997) proposed the modified test statistic, $M D M=N^{-1 / 2}\left[N+1-2 h+N^{-1} h(h-\right.$ 1) $]^{1 / 2} D M$, where $N$ is the number of forecasts, which corrects for small-sample bias. For Harvey et al. $(1997,1998)$, it is very doubtful that the forecast errors were normally distributed; they recommended using the Student's $t$ 
distribution with $(N-1)$ degrees of freedom rather than the standard normal distribution to test the null hypothesis.

Table 7 presents the normality test of the forecast errors based on the Jarque-Bera statistics. Contrary to Harvey et al.'s (1997) assumption, the hypothesis of normality of the forecast errors is highly believable, and there is no evidence that the forecast error distribution is heavy-tailed, unless for the Czech Republic at a horizon of one month. Therefore, we do not follow the recommendation of Harvey et al. $(1997,1998)$ to substitute the Student's $\mathrm{t}$ distribution to the normal distribution when testing for equal forecast accuracy (Table 8 ) or for forecast encompassing (Table 9). ${ }^{13}$

Table 7. Normality test of the forecast errors (Jarque-Bera test)

\begin{tabular}{|c|c|c|c|c|}
\hline \multicolumn{2}{|c|}{} & Hungary & Czech Republic & Poland \\
\hline \multirow{3}{*}{$h=1$} & OEM & $0.062(0.969)$ & $12.258(0.002)$ & $1.966(0.374)$ \\
\cline { 2 - 5 } & CEM & $0.016(0.991)$ & $13.861(0.001)$ & $1.050(0.591)$ \\
\hline \multirow{3}{*}{$h=3$} & OEM & $1.365(0.505)$ & $0.727(0.695)$ & $3.818(0.148)$ \\
\cline { 2 - 5 } & CEM & $0.956(0.619)$ & $0.692(0.707)$ & $2.270(0.321)$ \\
\hline \multirow{3}{*}{$h=12$} & OEM & $4.222(0.121)$ & $0.611(0.736)$ & $3.696(0.157)$ \\
\cline { 2 - 5 } & CEM & $3.995(0.135)$ & $0.533(0.766)$ & $3.469(0.176)$ \\
\hline \multirow{3}{*}{$h=24$} & OEM & $3.418(0.180)$ & $1.294(0.523)$ & $1.291(0.524)$ \\
\cline { 2 - 5 } & CEM & $3.465(0.176)$ & $1.376(0.502)$ & $2.063(0.356)$ \\
\hline
\end{tabular}

(Note) The $p$-values of the normality tests are in bracket below the Jarque-Bera statistics

Table 8 presents the results of the tests of equal forecast accuracy of the two forecasting models for each forecasting horizon for the three countries. The absolute value of the MDM statistic is low and is never above the critical value at the $10 \%$ level. For each country and each forecasting horizon, we cannot detect any notable difference in the forecast accuracy of the two models. However, this kind of test is characterized by a reduced power, which may prevent us from detecting a moderate difference in the forecast accuracy

${ }^{13} \mathrm{~N}$ might be considered large enough in our sample $(\mathrm{N}=59)$ to replace the Student's $\mathrm{t}$ distribution with the normal one, without affecting the results. 
of the models (Harvey et al. 1997, 1998).

Table 8. Tests of equal forecast accuracy (MDM statistic)

\begin{tabular}{|c|c|c|c|}
\hline & Hungary & Czech Republic & Poland \\
\hline$h=1$ & 1.223 & -0.455 & -0.306 \\
\hline$h=3$ & 1.206 & 0.972 & 0.693 \\
\hline$h=12$ & 0.457 & -1.593 & 1.409 \\
\hline$h=24$ & 1.277 & -1.538 & 1.510 \\
\hline
\end{tabular}

(Note) The MDM statistic is calculated as described by Harvey et al. (1997); it is positive (negative) if the RMSPE from the CEM-based forecasting model is higher (lower) than the RMSPE from the OEMbased version. As the test is two-sided, the absolute value of the MDM statistic is compared to the critical value, which is 1,645 at the $10 \%$ level.

In a complementary exercise, we test for forecast encompassing. Following Stock and Watson (1999), to detect a significant improvement of the forecasting, we define a forecast combination regression:

$$
\pi_{t+h}^{h}-\pi_{t}=\lambda f_{t, h}^{C E M}+(1-\lambda) f_{t, h}^{O E M}+\eta_{t+h}, \quad 0 \leq \lambda \leq 1
$$

where $f_{t, h}^{O E M}$ and $f_{t, h}^{C E M}$ are the two competing forecasts.

Equation (07) can alternatively be written with the forecast errors:

$$
e_{t, h}^{O E M}=\lambda\left(e_{t, h}^{O E M}-e_{t, h}^{C E M}\right)+\eta_{t+h}
$$

Estimation of Equation (8) allows us to test for forecasting encompassing. The objective is to assess whether the forecast $e_{t, h}^{C E M}$ contains useful forecasting information not contained in the alternative forecast, $e_{t, h}^{0 E M}$. The null hypothesis is $\lambda=0$ and the alternative is $\lambda>0$. When the null hypothesis is not rejected, the forecast $f_{t, h}^{O E M}$ is said to encompass the forecast, $f_{t, h}^{C E M}$. Additionally, the reverse model, $e_{t, h}^{C E M}=\lambda\left(e_{t, h}^{C E M}-e_{t, h}^{O E M}\right)+\eta_{t+h}$, must also be estimated with the null hypothesis, $\lambda=0$, to be tested against $\lambda>0$.

We first test these hypotheses with a $t$-statistic that is robust to heteroscedasticity and autocorrelation of order $h-1$. We also implement the 
MDM framework test of Harvey et al. (1998) for forecast encompassing. It is based on the two-loss differential, $d_{1 t}=e_{t}^{O E M}\left(e_{t}^{O E M}-e_{t}^{C E M}\right)$ and $d_{2 t}=e_{t}^{C E M}\left(e_{t}^{C E M}-e_{t}^{O E M}\right)$, used respectively for testing whether $f_{t}^{O E M}$ encompasses $f_{t}^{C E M}$ and whether $f_{t}^{C E M}$ encompasses $f_{t}^{O E M}$. The MDM test of Harvey et al. (2008) is based on the statistics, $M D M=N^{-1 / 2}\left[N+1-2 h+N^{-1} h(h-1)\right]^{1 / 2} D M$ , where $\mathrm{DM}=\bar{d} / \sigma_{\bar{d}}$ is successively calculated on the series $d_{1, t}$ and $d_{2, t}$ , with a consistent estimator, $\sigma_{\bar{d}}$ of the standard deviation of $\bar{d}$, robust to heteroscedasticity and autocorrelation of order $h-1$.

Table 9 presents the results of the encompassing tests for each forecasting horizon for the three countries. These results are consistent with those of Table 6, offering a more precise view of the ranking of the forecast models than the results of the tests of forecast accuracy equality (Table 8). Moreover, the results seem to be robust, as the two tests deliver the same conclusion, even if the MDM statistic exhibits a reduced power for the benefit of a more stable size.

For the Czech Republic, the OEM-based model encompasses the CEMbased version, whereas the reverse is not true at a horizon of three months. However, at longer horizons characterized by lower RMSPE, it is the CEMbased model that encompasses the OEM-based model. For Hungary, at horizons of one month, three months, and two years, the OEM-based model encompasses the CEM-based version. Additionally, for Poland, we notice the same phenomenon at horizons of three months, one year, and two years.

For the CEE countries exhibiting a stable long-run money-demand function, including a significant currency-substitution effect (i.e., Hungary and Poland), the OEM-based monetary overhang improves the forecast of inflation, comparatively to the CEM-based money overhang in the sense that the first forecast encompasses the second. For the CEE country that does not present a stable long-run money demand (i.e., the Czech Republic), the consideration of currency substitution does not improve the forecast of inflation. 
Table 9. Encompassing tests

\begin{tabular}{|c|c|c|c|c|c|}
\hline & & & Hungary & $\begin{array}{c}\text { Czech } \\
\text { Republic }\end{array}$ & Poland \\
\hline \multirow{6}{*}{$h=1$} & \multirow{3}{*}{$\begin{array}{c}f_{t}^{C E M} \\
\text { eneompassing } \\
f_{t}^{O E M}\end{array}$} & $\lambda$ & 2.099 & -0.025 & 0.244 \\
\hline & & $t$-statistic & $1.751 * *$ & -0.021 & 0.299 \\
\hline & & MDM & $1.547 *$ & -0.021 & 0.306 \\
\hline & \multirow{3}{*}{$\begin{array}{c}f_{t}^{O E M} \\
\text { eneompassing } \\
f_{t}^{C E M}\end{array}$} & $\lambda$ & -1.099 & 1.025 & 0.755 \\
\hline & & $t$-statistic & -0.917 & 0.876 & 0.928 \\
\hline & & MDM & -0.869 & 0.896 & 0.853 \\
\hline \multirow{6}{*}{$h=3$} & \multirow{3}{*}{$\begin{array}{c}f_{t}^{C E M} \\
\text { eneompassing } \\
f_{t}^{O E M} \\
\end{array}$} & $\lambda$ & 1.983 & 1.445 & 0.936 \\
\hline & & $t$-statistic & $2.130 * *$ & $1.687 * *$ & $1.560 *$ \\
\hline & & MDM & $1.481 *$ & $1.397 *$ & $1.416^{*}$ \\
\hline & \multirow{3}{*}{$\begin{array}{c}f_{t}^{O E M} \\
\text { eneompassing } \\
f_{t}^{C E M}\end{array}$} & $\lambda$ & -0.983 & -0.445 & 0.063 \\
\hline & & $t$-statistic & -1.056 & -0.519 & 0.106 \\
\hline & & MDM & -0.871 & -0.483 & 0.102 \\
\hline \multirow{6}{*}{$h=12$} & \multirow{3}{*}{$\begin{array}{c}f_{t}^{C E M} \\
\text { eneompassing } \\
f_{t}^{O E M}\end{array}$} & $\lambda$ & 1.289 & -0.725 & 1.291 \\
\hline & & $t$-statistic & 1.120 & -1.549 & $3.931 * * *$ \\
\hline & & MDM & 0.669 & -1.057 & $1.873 * *$ \\
\hline & \multirow{3}{*}{$\begin{array}{c}f_{t}^{O E M} \\
\text { eneompassing } \\
f_{t}^{C E M}\end{array}$} & $\lambda$ & -0.289 & 1.725 & -0.291 \\
\hline & & $t$-statistic & -0.251 & $3.684 * * *$ & -0.887 \\
\hline & & MDM & -0.189 & $2.013 * *$ & -0.643 \\
\hline \multirow{6}{*}{$h=24$} & \multirow{3}{*}{$\begin{array}{c}f_{t}^{C E M} \\
\text { eneompassing } \\
f_{t}^{O E M} \\
\end{array}$} & $\lambda$ & 1.786 & -1.837 & 1.878 \\
\hline & & $t$-statistic & $2.865 * * *$ & -3.079 & $13.079 * * *$ \\
\hline & & MDM & $1.496^{*}$ & -1.322 & $1.510^{*}$ \\
\hline & \multirow{3}{*}{$\begin{array}{c}f_{t}^{O E M} \\
\text { eneompassing } \\
f_{t}^{C E M}\end{array}$} & $\lambda$ & -0.786 & 2.837 & -0.878 \\
\hline & & $t$-statistic & -1.261 & $4.756 * * *$ & -6.116 \\
\hline & & MDM & -0.857 & $1.715^{* *}$ & -1.488 \\
\hline
\end{tabular}

(Notes) (i) The $t$-statistic is used for testing the null hypothesis $\lambda=0$ (the hypothesis of encompassing is not rejected) against the alternative hypothesis $\lambda>0$ (the hypothesis of encompassing is rejected).

(ii) The MDM statistic is calculated as described by Harvey et al. 1998).

(iii) Both statistics are robust to heteroscedasticity and autocorrelation of order $h-1$. 


\section{Robustness Analysis}

Our findings may, however, be influenced by the time span to which we refer. As shown by Figure 1 to 3, at the beginning of 2000s, the monetary overhang had a different path for the considered CEE countries. However, the trend was very similar after their EU accession. This evidence could influence the forecasting results of our models. Therefore, we conduct a similar investigation for the period of 2004 to 2016, where we check whether the monetary overhang is a good predictor of inflation and whether there are significant differences between the OEM and CEM.

We begin with a test of the overall significance of the inflation forecast model (Table 10). The results show that the inflation forecasts improve with the increase in time horizon, up to one year for Hungary and Poland. Second, the tests for exclusion of the monetary overhang measures in the forecasting regressions (Table 11) are in line with previous findings, which state that the OEM-based monetary overhang is a good predictor of inflation for Hungary, but not for the Czech Republic. However, a slight difference appears in this case of Poland, where it differs from the main results. The monetary overhang is not a good predictor of inflation for any models and time horizons under consideration.

\section{Table 10. Tests of the overall significance of the inflation forecasting model (2004 2016)}

\begin{tabular}{|c|c|c|c|c|}
\hline \multicolumn{2}{|c}{} & Hungary & Czech Republic & Poland \\
\hline \multirow{3}{*}{$h=1$} & OEM & $4.558(0.000)$ & $5.390(0.000)$ & $2.842(0.000)$ \\
\cline { 2 - 5 } & CEM & $4.610(0.000)$ & $5.114(0.000)$ & $2.856(0.000)$ \\
\hline \multirow{3}{*}{$h=3$} & OEM & $9.289(0.000)$ & $8.487(0.000)$ & $6.042(0.000)$ \\
\cline { 2 - 5 } & CEM & $9.034(0.000)$ & $8.293(0.000)$ & $6.155(0.000)$ \\
\hline \multirow{3}{*}{$h=12$} & OEM & $18.563(0.000)$ & $9.302(0.000)$ & $11.101(0.000)$ \\
\cline { 2 - 5 } & CEM & $18.392(0.000)$ & $13.291(0.000)$ & $11.799(0.000)$ \\
\hline \multirow{3}{*}{$h=24$} & OEM & $15.763(0.000)$ & $10.181(0.000)$ & $7.498(0.000)$ \\
\cline { 2 - 5 } & CEM & $14.712(0.000)$ & $18.197(0.000)$ & $7.944(0.000)$ \\
\hline
\end{tabular}

(Note) $P$-values of the hypothesis of nullity of the parameters of $\beta_{\pi}(L)$ and $\beta_{\hat{\varepsilon}}(L)$ are reported in brackets. 
Table 11. Tests of exclusion of the monetary overhang in the forecasting regressions (2004 2016)

\begin{tabular}{|c|l|c|c|c|}
\hline \multicolumn{2}{|c|}{} & Hungary & Czech Republic & Poland \\
\hline \multirow{3}{*}{$h=1$} & MO based on OEM & $1.278(0.236)$ & $1.097(0.368)$ & $0.394(0.969)$ \\
\cline { 2 - 5 } & MO based on CEM & $1.337(0.201)$ & $0.818(0.640)$ & $0.411(0.963)$ \\
\hline \multirow{3}{*}{$h=3$} & MO based on OEM & $2.520(0.004)$ & $0.581(0.864)$ & $0.516(0.910)$ \\
\cline { 2 - 5 } & MO based on CEM & $2.311(0.009)$ & $0.441(0.950)$ & $0.616(0.836)$ \\
\hline \multirow{2}{*}{$h=12$} & MO based on OEM & $3.470(0.000)$ & $0.371(0.975)$ & $0.864(0.592)$ \\
\cline { 2 - 5 } & MO based on CEM & $3.833(0.000)$ & $2.881(0.001)$ & $1.273(0.240)$ \\
\hline \multirow{2}{*}{$h=24$} & MO based on OEM & $2.569(0.004)$ & $0.278(0.993)$ & $0.586(0.859)$ \\
\cline { 2 - 5 } & MO based on CEM & $2.044(0.025)$ & $4.574(0.000)$ & $0.896(0.559)$ \\
\hline
\end{tabular}

(Note) $P$-values of the hypothesis of nullity of the parameters of $\beta_{\hat{\varepsilon}}(L)$ are reported in brackets

We continue the robustness check analysis and perform forecasting comparisons using a recursive out-of-sample technique. The RMSPE is reported in Table 12. As in the previous case, the RMSPE is a decreasing function of $\mathrm{h}$ up to a horizon, $h=12$, for all three countries. Additionally, the OEM-based forecasting regressions slightly outperform the CEM-based regression for Hungary and Poland for horizons of one month, three months, and two years.

Table 12. Root mean-squared prediction errors (2004 2016)

\begin{tabular}{|c|c|c|c|c|}
\hline \multicolumn{2}{|c|}{} & Hungary & Czech Republic & Poland \\
\hline \multirow{3}{*}{$h=1$} & OEM & 0.0354 & 0.0296 & 0.0179 \\
\cline { 2 - 5 } & CEM & 0.0353 & 0.0294 & 0.0180 \\
\hline \multirow{3}{*}{$h=3$} & OEM & 0.0244 & 0.0172 & 0.0144 \\
\cline { 2 - 5 } & CEM & 0.0247 & 0.0174 & 0.0145 \\
\hline \multirow{3}{*}{$h=12$} & OEM & 0.0173 & 0.0129 & 0.0113 \\
\cline { 2 - 5 } & CEM & 0.0171 & 0.0117 & 0.0107 \\
\hline \multirow{3}{*}{$h=24$} & OEM & 0.0201 & 0.0128 & 0.0105 \\
\cline { 2 - 5 } & CEM & 0.0204 & 0.0098 & 0.0130 \\
\hline
\end{tabular}


Next, we test for equal forecast accuracy, following Harvey et al. (1997). We first show that the standard normal distribution should be used to test the null hypothesis (Table 13).

Table 13. Normality test of the forecast errors (2014 2016)

\begin{tabular}{|c|c|c|c|c|}
\hline \multicolumn{2}{|c|}{} & Hungary & Czech Republic & Poland \\
\hline \multirow{3}{*}{$h=1$} & OEM & $0.555(0.757)$ & $5.904(0.052)$ & $0.529(0.767)$ \\
\cline { 2 - 6 } & CEM & $0.764(0.682)$ & $8.939(0.011)$ & $0.318(0.852)$ \\
\hline \multirow{3}{*}{$h=3$} & OEM & $0.842(0.656)$ & $0.571(0.751)$ & $0.640(0.726)$ \\
\cline { 2 - 5 } & CEM & $0.813(0.665)$ & $0.723(0.696)$ & $0.345(0.841)$ \\
\hline \multirow{3}{*}{$h=12$} & OEM & $1.056(0.589)$ & $2.914(0.232)$ & $3.667(0.159)$ \\
\cline { 2 - 5 } & CEM & $1.024(0.599)$ & $0.275(0.871)$ & $4.180(0.123)$ \\
\hline \multirow{2}{*}{$h=24$} & OEM & $3.228(0.199)$ & $2.382(0.303)$ & $0.324(0.850)$ \\
\cline { 2 - 5 } & CEM & $3.288(0.193)$ & $0.039(0.980)$ & $2.317(0.313)$ \\
\hline
\end{tabular}

(Note) The $p$-values of the normality tests are in bracket below the Jarque-Bera statistics.

Second, we present the results of the tests of equal forecast accuracy for the two forecasting models (the MDM statistic). Similar to the main results, we notice that the absolute value of the MDM statistic is lower than the critical value, showing no significant difference between the retained models (Table 14).

In summary, the OEM-based monetary overhang improves the inflation forecasts for Hungary and Poland and at particularly long horizons. This result is not confirmed for the Czech Republic, where the stability of the money-demand function is questionable. Additionally, the discrepancies between the two models for estimating the stability of money demand decrease after their EU accession. Our results partially contrast the findings reported by Horvath et al. (2011), who stated that money matters, but does not improve the predictability of inflation in the CEE countries. However, our findings explain why studies using CEMs for investigating money demand in CEE countries (Narayan 2010) report more cases of unstable money demand, whereas researchers who rely on open-economy specifications show that the money demand in CEE countries is generally stable (Dreger et al. 2007, 
Fidrmuc 2009).

Table 14. Tests of equal forecast accuracy (2004 2016)

\begin{tabular}{|c|c|c|c|}
\hline & Hungary & Czech Republic & Poland \\
\hline$h=1$ & -0.216 & -0.341 & 1.107 \\
\hline$h=3$ & 0.825 & 0.279 & 0.700 \\
\hline$h=12$ & -0.215 & -0.530 & -0.453 \\
\hline$h=24$ & 0.337 & -0.455 & -0.243 \\
\hline
\end{tabular}

(Note) Refer to Table 8.

For the last step, we test for forecast encompassing, considering our reduced sample (Table 15). Whereas the main results show that CEM-based model encompasses the OEM-based model for the Czech Republic and the reverse applies for Hungary and Poland, the robustness check shows no significant difference between the CEM and OEM. These findings confirm the equal forecast accuracy results (MDM statistics) but contradicts the outcomes of recursive out-of-sample comparisons and tests for the exclusion of the monetary overhang. 
Table 15. Encompassing tests (2004 2016)

\begin{tabular}{|c|c|c|c|c|c|}
\hline & & & Hungary & $\begin{array}{c}\text { Czech } \\
\text { Republic }\end{array}$ & Poland \\
\hline \multirow{6}{*}{$h=1$} & \multirow{3}{*}{$\begin{array}{c}f_{t}^{C E M} \\
\text { eneompassing } \\
f_{t}^{O E M}\end{array}$} & $\lambda$ & 0.255 & 0.246 & 2.970 \\
\hline & & $t$-statistic & 0.227 & 0.326 & 1.414 \\
\hline & & MDM & 0.228 & 0.321 & 1.305 \\
\hline & \multirow{3}{*}{$\begin{array}{c}f_{t}^{O E M} \\
\text { eneompassing } \\
f_{t}^{C E M}\end{array}$} & $\lambda$ & 0.744 & 0.753 & -1.970 \\
\hline & & $t$-statistic & 0.663 & 1.000 & -0.938 \\
\hline & & MDM & 0.647 & 1.034 & -0.898 \\
\hline \multirow{6}{*}{$h=3$} & \multirow{3}{*}{$\begin{array}{c}f_{t}^{C E M} \\
\text { eneompassing } \\
f_{t}^{O E M}\end{array}$} & $\lambda$ & 1.597 & 0.673 & 2.246 \\
\hline & & $t$-statistic & 1.229 & 1.128 & 1.002 \\
\hline & & MDM & 1.201 & 1.061 & 0.879 \\
\hline & \multirow{3}{*}{$\begin{array}{c}f_{t}^{O E M} \\
\text { eneompassing } \\
f_{t}^{C E M}\end{array}$} & $\lambda$ & -0.597 & 0.326 & -1.246 \\
\hline & & $t$-statistic & -0.459 & 0.547 & -0.555 \\
\hline & & MDM & -0.447 & 0.528 & -0.511 \\
\hline \multirow{6}{*}{$h=12$} & \multirow{3}{*}{$\begin{array}{c}f_{t}^{C E M} \\
\text { eneompassing } \\
f_{t}^{O E M}\end{array}$} & $\lambda$ & -0.263 & 0.231 & -0.574 \\
\hline & & $t$-statistic & -0.091 & 0.502 & -0.275 \\
\hline & & MDM & -0.074 & 0.444 & -0.233 \\
\hline & \multirow{3}{*}{$\begin{array}{c}f_{t}^{O E M} \\
\text { eneompassing } \\
f_{t}^{C E M}\end{array}$} & $\lambda$ & 1.263 & 0.768 & 1.574 \\
\hline & & $t$-statistic & 0.438 & 1.668 & 0.755 \\
\hline & & MDM & 0.357 & 1.048 & 0.688 \\
\hline \multirow{6}{*}{$h=24$} & \multirow{3}{*}{$\begin{array}{c}f_{t}^{C E M} \\
\text { eneompassing } \\
f_{t}^{O E M}\end{array}$} & $\lambda$ & 1.973 & 0.295 & -0.200 \\
\hline & & $t$-statistic & 0.752 & 1.421 & -0.110 \\
\hline & & MDM & 0.449 & 1.196 & -0.067 \\
\hline & \multirow{3}{*}{$\begin{array}{c}f_{t}^{O E M} \\
\text { eneompassing } \\
f_{t}^{C E M}\end{array}$} & $\lambda$ & -0.973 & 0.704 & 1.200 \\
\hline & & $t$-statistic & -0.371 & 3.392 & 0.662 \\
\hline & & MDM & -0.223 & 0.936 & 0.392 \\
\hline
\end{tabular}

(Note) Refer to Table 9. 


\section{Conclusions and Policy Implications}

A stable money-demand function shows the extent to which monetary aggregates matter in the conduct of monetary policy and allows us to test whether the monetary overhang is a good predictor of future inflation.

To provide additional insights into money-demand stability and to the role of money in predicting inflation in selected CEE countries, we compared two money-demand functions resulting from a closed and an open, micro founded money-demand model. This specification allows us to see whether the consideration of a currency-substitution effect makes the money demand more stable in the long run. Using monthly data for the Czech Republic, Hungary, and Poland for the period 1999 2016, our results can be summarized as follows.

First, considering the interest-rate differential (i.e., OEM) we obtained consistent results for money-demand stability, whereas we obtained a smaller extent for the Czech Republic. This result can be explained by the fact that the structure of money in circulation in the Czech Republic via the structure of bank deposits shows a higher proportion of domestic currency denominated deposits as compared to Hungary and Poland. There were about $90 \%$ of deposits in the Czech Republic, compared to $80 \%$ in the other two countries. The policy implications of these findings suggest that, in countries where the confidence in domestic currency is higher, the effect of currency substitution for monetary stabilization diminishes.

Second, we discovered that the monetary overhang generated from the OEM surpasses the monetary overhang estimated from the CEM, especially during the pre-crisis period. This observation favors a soft monetary stance before the crisis. However, this evidence raised questions about the forecasting capacity of the monetary overhang. Given the structural break that appeared in the monetary overhang in 2008 for all countries retained in the analysis, we see that our forecast exercises have limitations. However, our $F$-test confirms the cointegration results and states that the monetary overhang is a good predictor of inflation only for Hungary and Poland.

Third, the results of the forecasting exercises were mixed, and we could not detect a significant difference of forecast accuracy between the two competing models. On the one hand, we performed out-of-sample inflation forecasts. These results showed that prediction errors decreased with the 
time horizon until 12 months for all three countries, as confirmed by our robustness analysis. Nevertheless, the consideration of the monetary overhang in forecasting the inflation is recommended only for Poland, and to a smaller extent for Hungary.

Poland, as the other countries in our sample, has in place an inflationtargeting monetary strategy and a floating exchange-rate regime. However, as compared to the Czech Republic and Hungary, which have a trade openness of more than $160 \%$ of GDP, according to the World Bank statistics in 2014, the trade openness in Poland is about $90 \%$ of its GDP. This evidence partially contradicts the important role of international factors in explaining the money demand in Poland. However, the central bank of Poland announced an accommodating inflation-targeting policy to sustain economic growth and to achieve financial stability. Therefore, money becomes more important in predicting inflation when monetary policy becomes less restrictive. However, it helps predict inflation only in the long run.

We have tested the equal forecast accuracy of OEM- and CEM-based models. The MDM statistics (Harvey et al. 1997, 1998) did not highlight any notable differences in the forecast accuracy of the two models. This result was confirmed by the robustness check we performed for the period 2004 2016. Finally, we tested for forecast encompassing using forecast combination regression. In this case, the main findings show that, for the Czech Republic, the CEM-based model encompasses the OEM-based model at long horizons. An opposite situation is recorded for Hungary and Poland at horizons of three months, one year, and two years. However, the robustness check for encompassing tests showed no significant difference between the two models.

Our findings suggest that the open-economy specification of the money demand model gives more consistent results than the closed-economy version for Hungary and Poland. The ability of the OEM-based monetary overhang to better predict inflation can be met only for Hungary and Poland, and it increases with the time horizon.

Furthermore, for these countries, money matters in predicting inflation. We could not detect a significant difference in forecast accuracy between the two competing models, especially when we considered the post-EU accession period. However, the OEM-based forecast model encompassed the CEMbased version. 
Received 14 August 2018, Revised 16 October 2018, Accepted 9 November 2018

\section{References}

Albulescu, C. T., Pépin, D. and S. M. Miller. 2018. "The micro-foundations of an open economy demand: An application to the Central and Eastern European countries." University of Connecticut, Department of Economics, WP 2018-06.

Alvarez, F., Lucas, R. E. Jr. and W. E. Weber. "Interest rates and inflation." American Economic Review, 91, (2001): 219-225.

Arize, A. C., Harris, P., Kasibhatla, K. M., Malindretos, I. N. and M. Scoullis. "The values of the determinants and tests of stability of the money demand function of the United States." Review of Business, 32, (2012): 99-104.

Attanasio, O. P., Guiso, L. and T. Jappelli. "The demand for money, financial innovation, and the welfare cost of inflation: An analysis with household data." Journal of Political Economy, 110, (2002): 317-351.

Bahmani, S. "Stability of the demand for money in the Middle East." Emerging Markets Finance \& Trade, 44, (2008): 62-83.

Bahmani, S. and A. M. Kutan. "How stable is the demand for money in emerging economies?" Applied Economics, 42, (2010): 3307-3318.

Bahmani-Oskooee, M., Kutan, A. M. and D. Xi. "The impact of economic and monetary uncertainty on the demand for money in emerging economies." Applied Economics, 45, (2013): 3278-3287.

Belke, A. and R. Czudaj. "Is Euro Area money demand (still) stable? Cointegrated VAR versus single equation techniques." Applied Economics Quarterly, 56, (2010): 285-315. 
Belongia, M. T. and P. N. Ireland. "Money and output, Friedman and Schwartz revisited." Journal of Money, Credit and Banking, 48, (2016): 1223-1266.

Benati L., R. E. Lucas Jr., J. P. Nicolini, and W. Weber. “International evidence on long run money demand." NBER Working Paper, (2016): 22475.

Biscarri, J. G., Moreno, A. and F. P. de Gracia. "Money demand accommodation, Impact on macro-dynamics and policy consequences." Journal of Policy Modeling, 32, (2010): 138-154.

Brand, C. and N. Cassola. "A money demand system for Euro Area M3." Applied Economics, 36, (2004): 817-838.

Bruggeman, A., Donati, P. and A. Warne. 2003. Is the demand for Euro Area M3 stable?. European Central Bank Working Paper no. 255, Frankfurt am Main.

Buch, C. M. "Money demand in Hungary and Poland." Applied Economics, 33, (2001): 989-999.

Budina, N., Hanousek, J. and Z. Tůma. "Money demand and seigniorage in transition." Eastern European Economics, 33, (1995): 54-73.

Cagan, P. 1956. The monetary dynamics of hyperinflation, in Friedman, M. (ed.), Studies in the Quantity Theory of Money, pp. 25-117, Chicago, University of Chicago Press.

Capasso, S. and O. Napolitano. "Testing for the stability of money demand in Italy, has the Euro influenced the monetary transmission mechanism?" Applied Economics, 44, (2012): 3121-3133.

Carstensen, K., Hagen, J., Hossfeld, O. and A. S. Neaves. "Money demand stability and inflation prediction in the four largest EMU countries." Scottish Journal of Political Economy, 56, (2009): 73-93. 
Chawluk, A. and R. Cross. "Measures of shortage and monetary overhang in the Polish economy." The Review of Economics and Statistics, 79, (1997): 105115 .

Clausen, V. and J-R. Kim. “The long-run stability of European money demand." Journal of Economic Integration, 15, (2000): 486-505.

Coenen, G. and J. L. Vega. "The demand for M3 in the Euro Area." Journal of Applied Econometrics, 16, (2001): 727-748.

Cziráky, D. and M. Gillman. "Money demand in an EU accession country, a VECM study of Croatia." Bulletin of Economic Research, 58, (2006): 03073378 .

Delatte, A-L., Fouquau, J. and Holz, C., "Explaining money demand in China during the transition from a centrally planned to a market-based monetary system." Post-Communist Economies, 26, (2014): 376-400.

De Santis, R. A., Favero, C. A. and B. Roffia. "Euro Area money demand and international portfolio allocation, A contribution to assessing risks to price stability. Journal of International Money and Finance, 32, (2013): 377-404.

Diebold, F. X. and R. S. Mariano. "Comparing predictive accuracy.” Journal of Business and Economic Statistics, 13, (1995): 253-263.

Dreger, C., Reimers, H-E. and B. Roffia. "Long run money demand in the new EU member states with exchange rate effects." Eastern European Economics, 45, (2007): 75-94.

Dreger, C. and J. Wolters. "Money demand and the role of monetary indicators in forecasting Euro Area inflation." International Journal of Forecasting, 30, (2014): 303-312.

Eckstein, Z. and L. Leiderman. "Seigniorage and the welfare cost of inflation, 
evidence from an intertemporal model of money and consumption." Journal of Monetary Economics, 29, (1992): 389-410.

El-Shagi, M. and S. Giesen. "Money and inflation, Consequences of the recent monetary policy." Journal of Policy Modeling, 35, (2013): 520-537.

Ewing, B. T. and J. E. Payne. "Some recent international evidence on the demand for money. Studies in Economics and Finance, 19, (1999): 84-107.

Fidrmuc J. "Money demand and disinflation in selected CEECs during the accession to the EU." Applied Economics, 41, (2009): 1259-1267.

Friedman, M. and A. J. Schwartz. 1963. A monetary history of the United States, 1867-1960. Princeton, Princeton University Press.

Friedman, B. M. and K. N. Kuttner. "Money, income, prices, and interest rates." American Economic Review, 82, (1992): 472-492.

Golinelli, R. and S. Pastorello. "Modelling the demand for M3 in the Euro Area." European Journal of Finance, 8, (2002): 371-401.

Hansen, B. E. "Tests for parameter instability in regressions with I(1) processes." Journal of Business and Economic Statistics, 10, (1992): 321-335.

Harvey, D. I., Leybourne, S. J. and P. Newbold. "Testing the equality of prediction mean squared errors." International Journal of Forecasting, 13, (1997): 281-291.

Harvey, D. I., Leybourne, S. J. and P. Newbold. "Tests for forecasting encompassing. Journal of Business and Economic Statistics, 16, (1998): 254259.

Hoque, A. and N. Al-Mutairi. "Financial deregulation, demand for narrow money and monetary policy in Australia." Applied Financial Economics, 6, 
(1996): 301-305.

Horváth, R., Komárek, L. and F. Rozsypal. "Does money help predict inflation? An empirical assessment for Central Europe.” Economic Systems, 35, (2011): $523-536$.

Ireland, P. N. "On the welfare cost of inflation and the recent behavior of money demand." American Economic Review, 99, (2009): 1040-1052.

Johansen, S. "Identifying restrictions of linear equations - with applications to simultaneous equations and cointegration." Journal of Econometrics, 69, (1995): 111-132.

Kumar, S. and D. J. Webber. "Australasian money demand stability, application of structural break tests." Applied Economics, 45, (2013): 1011-1025.

Laumas, G. S. and Y. P. Mehra. "The stability of the demand for money function, 1900-1974." The Journal of Finance, 32, (1977): 911-916.

Leventakis J. A. "Modelling money demand in open economies over the modern floating rate period.” Applied Economics, 25, (1993): 1005-1012.

Lin, K-P. and J. S. Oh. "Stability of the U.S. short run money demand function, 1959-81." The Journal of Finance, 39, (1984): 1383-1396.

Liu, J. and C. J. M. Kool. "Money and credit overhang in the euro area." Economic Modelling, 68, (2018): 622-633.

Lucas, R. E. Jr. and J. P. Nicolini. "On the stability of money demand.” Journal of Monetary Economics, 73, (2015): 48-65.

Makin, A. J., Robson, A. and S. Ratnasiri. "Missing money found causing Australia's inflation.” Economic Modelling, 66, (2017): 156-162.

Miller, S. M., Martins, L. F. and R. Gupta. "A time-varying approach of the US 
welfare cost of inflation." Macroeconomic Dynamics, (2017): 1-23. doi,10.1017/ S1365100517000037.

Narayan, P. K. "Modelling money demand for a panel of eight transitional economies." Applied Economics, 42, (2010): 3293-3305.

Nyblom, J. "Testing for the constancy of parameters over time." Journal of the American Statistical Association, 84, (1989): 223-230.

Pesaran, M. H., Shin, Y. and R. J. Smith. "Bounds testing approaches to the analysis of level relationships." Journal of Applied Econometrics, 16, (2001): 289-326.

Phillips, P., and B. Hansen. "Statistical inference in instrumental variables regression with I(1) processes." Review of Economic Studies, 57, (1990): 99125 .

Rao, B. B. and S. Kumar. "A panel data approach to the demand for money and the effects of financial reforms in the Asian countries." Economic Modelling, 26, (2009): 1012-1017.

Saikkonen, P. "Asymptotically efficient estimation of cointegration regressions." Econometric Theory, 7, (1991): 1-21.

Setzer, R. and G. B. Wolff. "Money demand in the Euro Area, New insights from disaggregated data." International Economics and Economic Policy, 10, (2013): 297-315.

Stock, J. H., and M. W. Watson. "A simple estimator of cointegrating vectors in higher order integrated systems." Econometrica, 61, (1993): 783-820.

Stock, J. H., and M. W. Watson. "Forecasting inflation." Journal of Monetary Economics, 44, (1999): 293-335. 
Taylor, J. B., "The robustness and efficiency of monetary policy rules as guidelines for interest rate setting by the European Central Bank." Journal of Monetary Economics, 43, (1999): 655-679.

Teles, P., Uhlig, H. and J. V. e Azevedo. "Is quantity theory still alive?" The Economic Journal, 126, (2015): 442-464.

Wu, C-S., Lin, J-L., Tiao, G. C. and D. D. Cho. "Is money demand in Taiwan stable? Economics Modelling, 22, (2003): 327-346. 


\section{Appendix 1: Data description}

\section{Table A1. Description of variables}

\begin{tabular}{|l|c|l|}
\hline \multicolumn{1}{|c|}{ Variables } & Database & \multicolumn{1}{c|}{ Explanations } \\
\hline $\begin{array}{l}m=M / P \\
\text { (real money) }\end{array}$ & $\begin{array}{c}\text { OECD } \\
\text { IFS (IMF) }\end{array}$ & $\begin{array}{l}M \text { - Broad Money (M3) Index }(2010=100), \\
\text { seasonally adjusted. } \\
P \text { - Consumer Prices Index }(2010=100) .\end{array}$ \\
\hline$y$ (output) & IFS (IMF) & $\begin{array}{l}\text { Industrial Production Index }(2010=100), \\
\text { seasonally adjusted. }\end{array}$ \\
\hline $\begin{array}{l}r \text { (domestic } \\
\text { interest rate) }\end{array}$ & Eurostat & $\begin{array}{l}\text { 1-month Money Market Rate for the Czech } \\
\text { Republic, Hungary and Poland. }\end{array}$ \\
\hline $\begin{array}{l}r^{*} \text { (Euro Area } \\
\text { interest rate) }\end{array}$ & Eurostat & 1-month Money Market Rate for the Euro Area. \\
\hline
\end{tabular}

\section{Appendix 2: Stability of money demand (robustness analysis)}

Table A2. Estimation results (2004 2016)

\begin{tabular}{|c|c|c|c|c|c|c|}
\hline \multirow{2}{*}{$\begin{array}{c}\text { Coeffi- } \\
\text { cient }\end{array}$} & \multicolumn{2}{|c|}{ Hungary } & \multicolumn{2}{c|}{ Czech Republic } & \multicolumn{2}{c|}{ Poland } \\
\cline { 2 - 7 } & OEM & CEM & OEM & CEM & OEM & CEM \\
\hline \multirow{2}{*}{$\alpha_{0}$} & $-2.040^{*}$ & $-1.703^{*}$ & $-7.977^{* * *}$ & $-6.710^{* * *}$ & $-6.410^{* * *}$ & $-6.808^{* * *}$ \\
& $(-1.854)$ & $(-1.706)$ & $(-14.377)$ & $(-8.815)$ & $(-19.395)$ & $(-16.016)$ \\
\hline \multirow{2}{*}{$\alpha_{1}$} & $0.436^{*}$ & $0.371 *$ & $1.712^{* * *}$ & $1.455^{* * *}$ & $1.412 * * *$ & $1.497 * * *$ \\
& $(1.914)$ & $(1.787)$ & $(14.552)$ & $(8.959)$ & $(21.029)$ & $(17.419)$ \\
\hline \multirow{2}{*}{$\alpha_{2}$} & -0.011 & -0.011 & -0.008 & $-0.057 * * *$ & $-0.038^{* * *}$ & $-0.023 * *$ \\
& $(-1.478)$ & $(-1.620)$ & $(-0.809)$ & $(-4.304)$ & $(-4.705)$ & $(-2.400)$ \\
\hline \multirow{2}{*}{$\alpha_{3}$} & 0.005 & & $0.148^{* * *}$ & & $0.016^{* *}$ & \\
\hline
\end{tabular}

(Notes) (i) The $t$-statistics are in bracket below the estimated long run parameters

(ii) $* * *, * *, *$ means significance at $1 \%, 5 \%$ and $10 \%$ significance level. 
Table A3. Tests of the hypothesis $\alpha_{1}=1$ (2004 2016)

\begin{tabular}{|c|c|c|c|c|c|c|}
\hline \multirow{2}{*}{} & \multicolumn{2}{|c|}{ Hungary } & \multicolumn{2}{c|}{ Czech Republic } & \multicolumn{2}{c|}{ Poland } \\
\cline { 2 - 7 } & OEM & CEM & OEM & CEM & OEM & CEM \\
\hline$t$-statistic & -2.475 & -3.030 & 6.054 & 2.804 & 6.139 & 5.785 \\
(probability) & $(0.014)$ & $(0.002)$ & $(0.000)$ & $(0.005)$ & $(0.000)$ & $(0.000)$ \\
\hline
\end{tabular}

Table A4. Results of the cointegration tests (Hansen's parameter instability tests) (2004 2016)

\begin{tabular}{|c|c|c|c|c|c|c|}
\hline \multirow{2}{*}{} & \multicolumn{2}{|c|}{ Hungary } & \multicolumn{2}{c|}{ Czech Republic } & \multicolumn{2}{c|}{ Poland } \\
\cline { 2 - 7 } & OEM & CEM & OEM & CEM & OEM & CEM \\
\hline LC statistic & 1.161 & 1.113 & 0.846 & 0.421 & 0.514 & 0.364 \\
(probability) & $(<0.01)$ & $(<0.01)$ & $(0.046)$ & $(0.072)$ & $(>0.2)$ & $(0.106)$ \\
\hline
\end{tabular}

